\title{
Invasive ductal carcinoma: relationship between pathological characteristics and the presence of axillary metastasis in $\mathbf{2 2 0}$ cases
}

\section{Carcinoma ductal invasor: relação de características anatomopatológicas com a presença de metástases axilares em 220 casos}

Ranniere Gurgel Furtado de Aquino ${ }^{1,3}$; Paulo Henrique Diógenes Vasques, TCBC-CE; Diane Isabelle Magno Cavalcante ${ }^{2}$; Ayane Layne de Sousa Oliveira3; Bruno Masato Kitagawa de Oliveira4; luiz Gonzaga Porto Pinheiro, ECBC-CE5

\section{A B S T R A C T}

\begin{abstract}
Objective: to analyze the relation of anatomopathological features and axillary involvement in cases of invasive ductal carcinoma. Methods: this is a cross-sectional study of 220 breast cancer patients submitted to radical mastectomy or quadrantectomy with axilar emptying, from the Mastology Service of the Assis Chateaubriand Maternity School, Ceará, Brazil. We submitted the tumors to histological processing and determined the histological (HG), tubular (TG) and nuclear (NG) grades, and the mitotic index (MI) by the classification of Scarff-BloomRichadson, verified the presence of angiolymphatic invasion (AI) and measured the largest tumor diameter (TD). We then correlated these variables with the presence of axillary metastases. Results: the mean patients'age was 56.81 years \pm 13.28 . Tumor size ranged from 0.13 to $22 \mathrm{~cm}$, with an average of 2.23cm \pm 2.79 . HG3, TG3 and NG3 prevailed, respectively 107 (48.6\%), 160 (72.7\%) and 107 (48.6\%). Mitotic indexes 1, 2 and 3 presented a homogeneous distribution, respectively 82 (37.2\%), 68 (31\%) and 70 (31.8\%). We observed no relation between the HG, TG and NG with the occurrence of axillary metastases ( $p=0.07, p=0.22$ and $p=0.21$, respectively). Mitotic indices 2 and 3 were related with the occurrence of axillary metastases $(p=0.03$ ). Tumors larger than $2 \mathrm{~cm}$ and cases that presented angiolymphatic invasion had a higher index of axillary metastases $(p=0.0003$ and $p<0.0001)$. Conclusion: elevated mitotic indexes, tumors with a diameter greater than $2 \mathrm{~cm}$ and the presence of angiolymphatic invasion were individuallyassociated with the occurrence of axillary metastases.
\end{abstract}

Keywords: Breast Neoplasms. Lymphatic Metastasis. Pathology, Surgical. Neoplasm Grading.

\section{INTRODUCTION}

$\mathrm{B}$ reast cancer is the most common malignant neoplasm in the world and still accounts for a number of unfavorable outcomes that make it the second leading cause of cancer death in women ${ }^{1}$. The variety of outcomes observed in clinical practice demonstrates that the biological behavior of this disease can still be uncertain and often does not depend on the type of treatment offered to the patient, which indicates that the mechanisms involved in this process are not fully known.

Morphological, genetic and enzymatic methods allow us to evaluate its degree of aggressiveness and are routinely used satisfactorily ${ }^{2,3}$. Anatomopathological analysis, due to its simplicity, speed and low-cost, is still widely used for its reliability even in the face of current molecular and genetic approaches ${ }^{4}$.

The tumor histological grade $(\mathrm{HG})$ is one of the most important anatomopathological features. The Nottingham classification system, which is a modification of the Scarff-Bloom-Richardson (SBR) ${ }^{5,6}$ one, is the most commonly used classification system to determine HG in breast cancer ${ }^{7}$. In 1991, its prognostic value was demonstrated for the first time ${ }^{5}$, and since then several studies have validated it, which has made it a recommended classification system worldwide ${ }^{8,9}$.

In breast cancer, HG indicates the degree of tumor tissue differentiation, established through a semiquantitative evaluation of the tumor's morphological characteristics: tubular grade (TG), pleomorphism or nuclear grade (NG), and Number of mitoses per large increase field - mitotic index $(\mathrm{MI})^{5}$.

1 - Federal University of Ceará (UFC), Post-graduation Program in Surgery, Fortaleza, Ceara State, Brazil. 2 - Federal University of Ceará (UFC), Department of Pathology and Legal Medicine, Fortaleza, Ceara State, Brazil. 3 - University of Fortaleza (UNIFOR), Faculty of Medicine, Fortaleza, Ceara State, Brazil. 4 - Federal University of Ceara (UFC), Faculty of Medicine, Fortaleza, Ceara State, Brazil. 5 - Federal University of Ceará (UFC), Department of Surgery, Fortaleza, Ceara State, Brazil. 
Another aspect analyzed is the tumor size. Currently, it has a high prognostic value, since it is highly related to disease aggressiveness. Tumors with larger diameters are associated with axillary lymph node involvement, lower disease free interval, and mortality. Small tumors are invariably related to a better prognosis both for overall survival and diseasefree time ${ }^{10,11}$.

Regarding the presence of angiolymphatic invasion, it is known that the involvement of peritumoral blood and lymphatic vessels is necessary for metastasis to occur in most cases. In cases of breast cancer, these findings are directly associated with axillary lymph node involvement and worse prognoses ${ }^{12-14}$.

The axillary status reflects the involvement or not of the axillary lymph nodes by neoplastic cells. It is one of the most important prognostic factors of invasive carcinoma, since patients with diseasefree armpits display better prognosis, both for overall and for disease-free survival. Survival at ten years is associated with the number of lymph nodes involved ${ }^{15}$.

Due to its indisputable clinical applicability and the different outcomes still observed in our clinical practice, this study aimed to verify the relationship between the tumor anatomopathological characteristics and the axillary metastatic involvement, since this is an excellent predictor of aggression and prognosis.

\section{METHODS}

This is a cross-sectional study based on the histopathological analysis of surgical specimens of patients with breast cancer of the invasive ductal histological subtype who underwent surgical treatment by mastectomy or quadrantectomy and investigation of the presence of axillary metastases by sentinel lymph node biopsy or axillary emptying. The patients were treated at the Mastology Service of the Assis Chateaubriand School Maternity from January 2005 to December 2014, and we carried out the research at the Department of Pathology and Legal Medicine DPML -, Faculty of Medicine of the Federal University of Ceará (UFC), between February and May 2015.

We selected female patients with confirmed histological diagnosis of invasive ductal carcinoma, regardless of age, who did not undergo neoadjuvant chemotherapy. We excluded cases that did not have sufficient material in good condition for histological processing and evaluation or did not meet the selection criteria.

The following variables were analyzed: Nuclear Grade (NG), Tubular Grade (TG), Mitotic Index (MI) and Histological Grade (HG) by the ScarfBloom-Richardson (SBR) method modified by Elston and Ellis ${ }^{5}$, which considers the sum of the tubular, nuclear and mitotic index scores (Table 1). We also studied the presence of angiolymphatic invasion,

Table 1. Scores for assessment of tubular and nuclear grades, and mitotic index.

\begin{tabular}{|c|c|c|}
\hline Criteria & Description & Score \\
\hline \multirow[t]{4}{*}{ Tubular Grade } & Tubular formation present in: & \\
\hline & More than $75 \%$ of the tumor. & 1 \\
\hline & 10 to $75 \%$ of the tumor. & 2 \\
\hline & Less than $10 \%$ of the tumor. & 3 \\
\hline \multirow[t]{3}{*}{ Nuclear Grade } & Mild nuclear atypia. Regular and uniform small cores. & 1 \\
\hline & Moderate nuclear atypia. Moderate size and variability. & 2 \\
\hline & Intense nuclear atypia. Striking variability and the presence of nucleoli. & 3 \\
\hline \multirow[t]{3}{*}{ Mitotic Index * } & 0 to 5 mitoses per large magnification field. & 1 \\
\hline & 6 to 10 mitoses per large magnification field. & 2 \\
\hline & More than 11 mitosis per large magnification field. & 3 \\
\hline
\end{tabular}

* For Nikon microscope (0.44 mm field diameter and 40x magnification). 

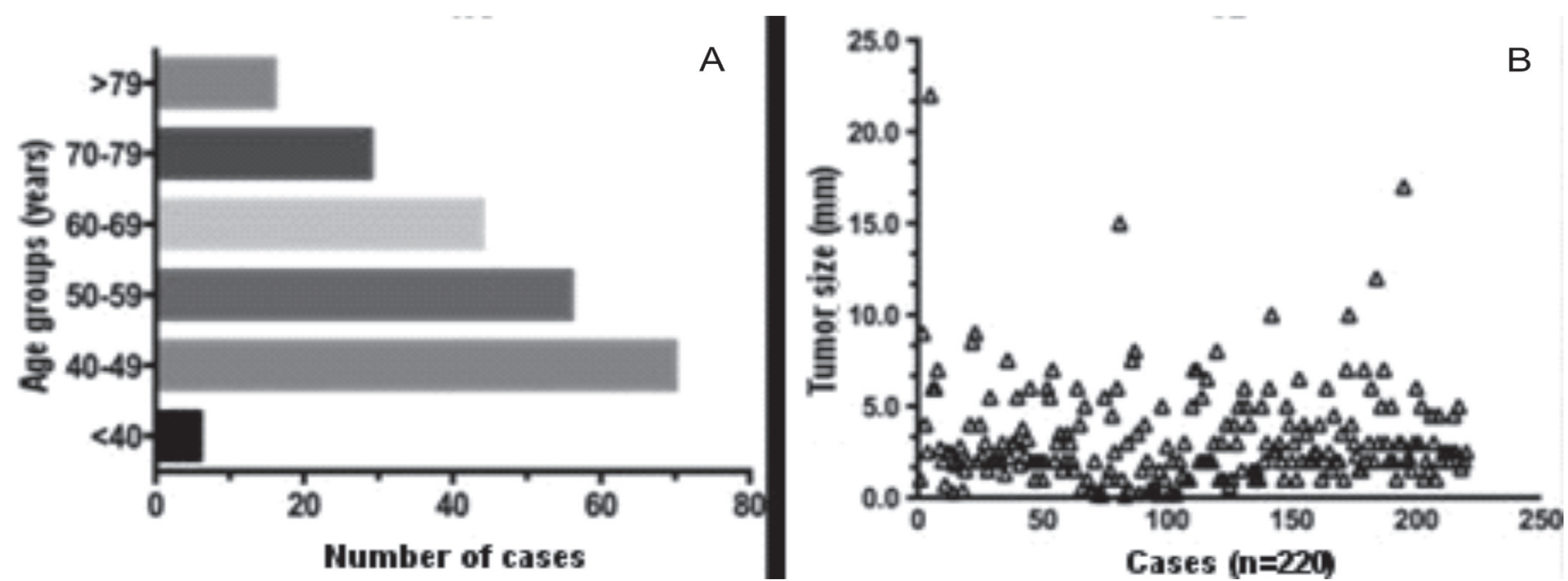

Figure 1. A) Distribution of casuistry by age group ( $n=220) ; B)$ Distribution of tumor size by its largest diameter in centimeters, according to the number of cases $(n=220)$.

metastasis to axillary lymph nodes and tumor diameter. We made the histological sections $5 \mu \mathrm{m}$ thick, processed them from the paraffin-embedded tumor tissue stained with Hematoxylin and Eosin (HE) and observed them under light microscopy (Nikon CX40 model microscope).

We considered: HG 1- Well differentiated (sum of 3 to 5 scores); HG 2- Moderately differentiated (sum of 6 to 7 scores); HG 3- Poorly differentiated (sum of 8 to 9 scores).

We confirmed angiolymphatic invasion (Al) by histopathological examination and considered it present when tumor cells invaded the lumen of blood vessels and/or peritumoral lymphatic vessels.

We assessed axillary metastases ( $\mathrm{Mx}$ ) by the histopathological study of lymph nodes harvested during surgery. We considered the cases positive for axillary metastasis when we found the presence of breast tissue neoplastic cells infiltrating the lymph nodes.

We measured tumor diameter (TD) in centimeters from the specimen sent to anatomopathological study. For this study, we considered the largest diameter measured in the primary tumor.

We performed statistical analysis using the SPSS $®$ software version 20.0, using the chisquare test, in order to show the correlation of each anatomopathological variable with the presence or absence of axillary metastases, considering $p<0.05$ as statistically significant.
This study was approved by the Ethics in Research Committee of the Pro-Rectory of Research of the Federal University of Ceará, via Plataforma Brasil, under the number 651,657.

\section{RESULTS}

We studied 220 cases of invasive ductal carcinoma. The mean patients'age was 56.81 years \pm 13.28 . The minimum age was 35 years and the maximum, 93, and the patients less than 50 years old predominated (Figure 1A). Tumor size ranged from 0.13 to $22 \mathrm{~cm}$, with a mean of $2.23 \mathrm{~cm} \pm 2.79$; we also recorded isolated cases of extensive tumors (Figure 1B).

When analyzing the degree of differentiation of the tumors regarding the histological grade and its variables, we observed a predominance of poorly differentiated tumors. HG3, TG3 and NG3 prevailed in this series, respectively 107 (48.6\%), 160 (72.7\%) and 107 (48.6\%). Mitotic indexes 1, 2 and 3 presented a homogeneous distribution in this study, respectively $82(37.2 \%), 68$ (31\%) and 70 (31.8\%) (Table 2).

We classified tumors according to their largest diameter and distributed them in two groups: less than or equal to $2 \mathrm{~cm}$ and greater than $2 \mathrm{~cm}$. Tumor $\leq 2.0 \mathrm{~cm}$ were more prevalent $(142-65.5 \%)$. The involvement of peritumoral blood and/or lymphatic vessels was present in most of the cases studied, being represented by $65 \%$ of the sample $(n=144)$ (Table 2$)$. 
Table 2. Distribution of frequencies of anatomopathological variables according to the occurrence of axillary metastases.

\begin{tabular}{|c|c|c|c|c|c|}
\hline & & Axillary $\mathrm{N}$ & tasis (Mx) & & \\
\hline Variable & & $\begin{array}{l}\text { Absent } \\
(\mathrm{n}-\%)\end{array}$ & $\begin{array}{c}\text { Present } \\
(\mathrm{n}-\%)\end{array}$ & $\begin{array}{c}\text { Total } n=220 \\
(n / \%)\end{array}$ & p-value \\
\hline & 1 & $22-10 \%$ & $22-10 \%$ & $44-20 \%$ & 0.0743 \\
\hline Histological Grade (HG) & 2 & $23-10.5 \%$ & $46-21 \%$ & $69-31.4 \%$ & \\
\hline & 3 & $33-15 \%$ & $74-33.6 \%$ & $107-48.6 \%$ & \\
\hline & 1 & $8-3.6 \%$ & $11-5 \%$ & $19-8.6 \%$ & 0.2207 \\
\hline Tubular Grade (TG) & 2 & $10-4.5 \%$ & $31-14 \%$ & $41-18.6 \%$ & \\
\hline & 3 & $61-27.7 \%$ & $99-45 \%$ & $160-72.7 \%$ & \\
\hline & 1 & $18-8.2 \%$ & $21-9.5 \%$ & $39-17.7 \%$ & 0.2131 \\
\hline Nuclear Grade (NG) & 2 & $28-12.7 \%$ & $46-21 \%$ & $74-33.65 \%$ & \\
\hline & 3 & $33-15 \%$ & $74-33.6 \%$ & $107-48.6 \%$ & \\
\hline & 1 & $38-17.3 \%$ & $44-40 \%$ & $82-37.2 \%$ & 0.039 \\
\hline Mitotic Index (Mi) & 2 & $19-8.6 \%$ & $49-22.3 \%$ & $68-31 \%$ & \\
\hline & 3 & $21-9.6 \%$ & $49-22.3 \%$ & $70-31.8 \%$ & \\
\hline Tumor diametor (TD) & $\leq 2 \mathrm{~cm}$ & $38-17.3 \%$ & $40-18.1 \%$ & $78-35.5 \%$ & 0.0003 \\
\hline lumor alameter (ID) & $>2 \mathrm{~cm}$ & $34-15.5 \%$ & $108-49 \%$ & $142-65.5 \%$ & \\
\hline Anginlymphatis lnwa & Absent & $58-26.4 \%$ & $18-8.2 \%$ & $76-34.5 \%$ & $<0.0001$ \\
\hline Angıolympnatıc Invasıon (Al) & Present & $19-8.6 \%$ & $125-56.8 \%$ & $144-65.5 \%$ & \\
\hline
\end{tabular}

When relating the histological grades and their variables with the presence of axillary metastases, we observed that the variables that prevailed in the cases with metastatic disease were those that indicated less tissue differentiation: HG3, TG3 and NG3. However, when analyzing the relation with the occurrence of axillary metastases, we found no statistical significance, with $p=0.07$, $p=0.22$ and $p=0.21$, respectively (Figures 2A, 2B and $3 \mathrm{~A})$.

When analyzing the number of mitoses per microscopic field, we observed that the highest mitotic indexes was significantly related $(p=0.03)$ with the occurrence of axillary metastases (Figure 3B).

Tumor diameter and angiolymphatic invasion were also statistically correlated with

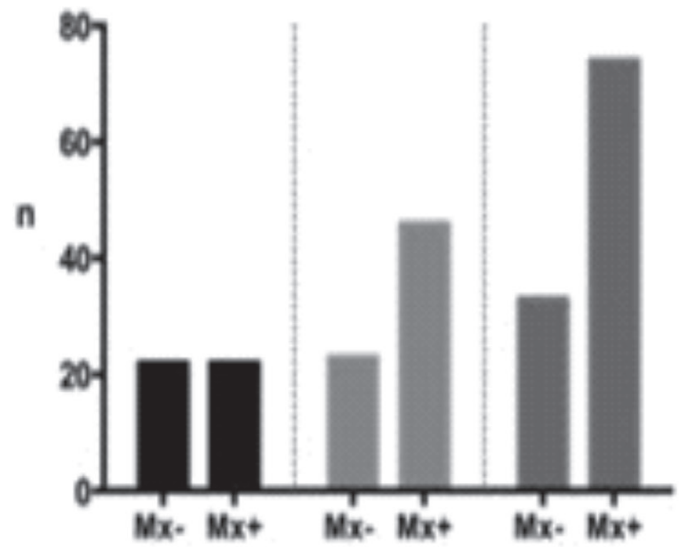

Histological grade $X$ axillary metastasis

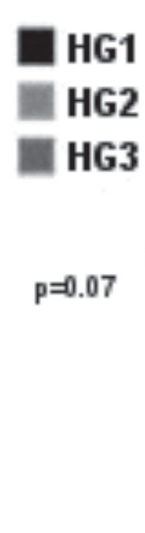

A

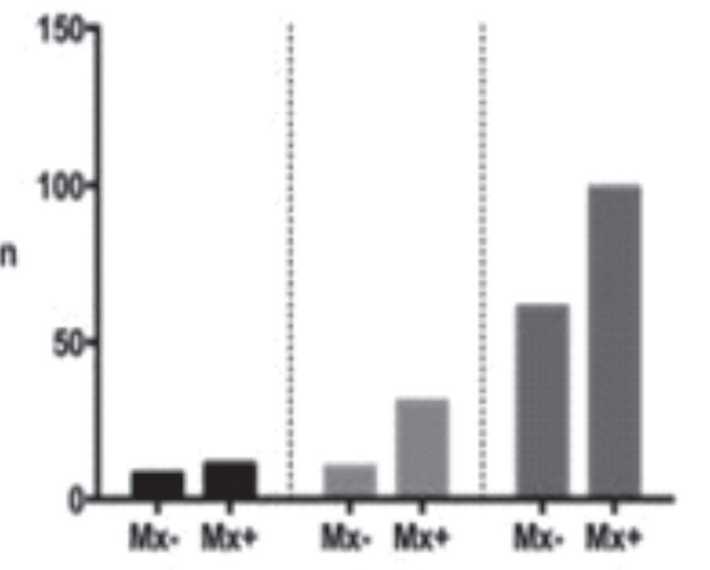

Tubular grade $\mathbf{X}$ axillary metastasis

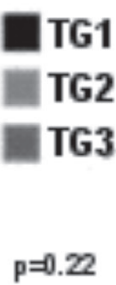

$\mathrm{p}=0.22$

\section{B}

Figure 2. Grouped distribution according to the metastatic involvement of axillary lymph nodes $(n=220)$. A) Histological grade; B) Tubular grade. 


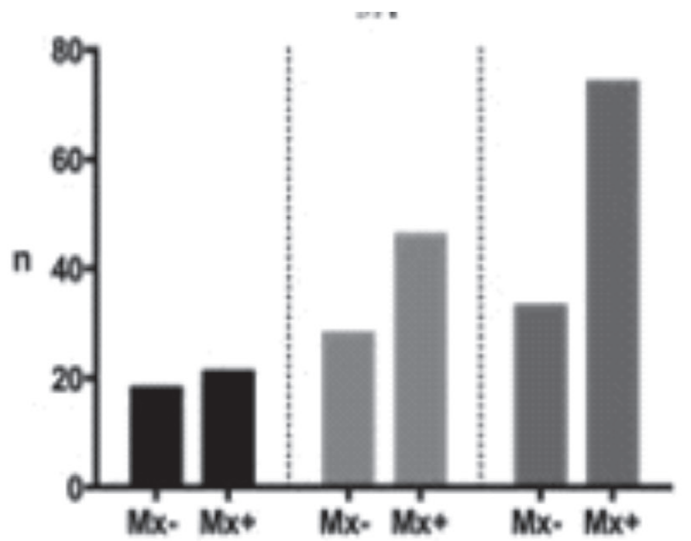

Nuclear grade $\mathbf{X}$ axillary metatasis

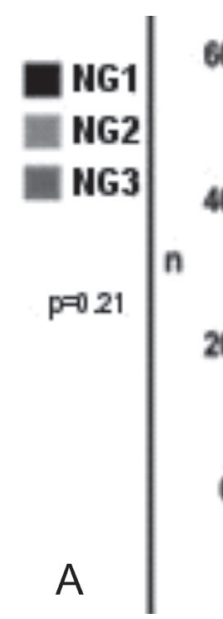

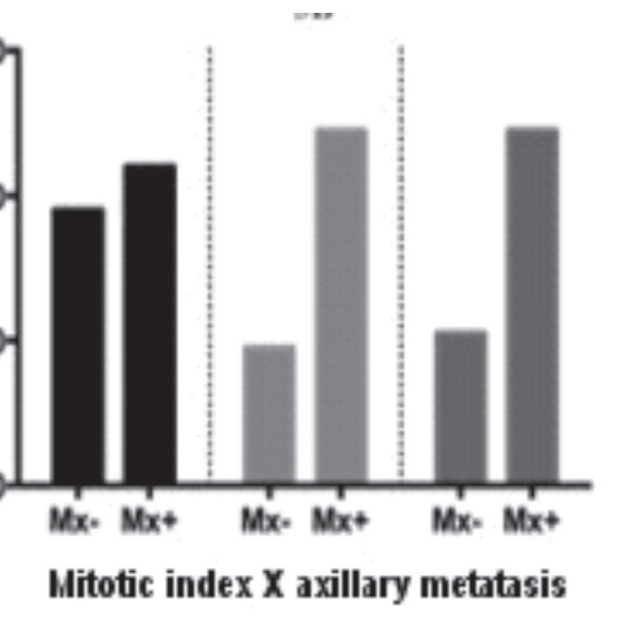

MI1 피는

IMI3

$p=0.03$

Figure 3. Grouped distribution according to the metastatic involvement of axillary lymph nodes $(n=220)$. A) Nuclear Grade; B) Mitotic index.

axillary involvement in the present study. The group of cases that presented tumors $>2.0 \mathrm{~cm}$ in their largest diameter and cases in which angiolymphatic invasion was present presented more axillary metastases, with $p=0.0003$ and $p<0.0001$, respectively (Figure 4 ).

\section{DISCUSSION}

Breast cancer has several outcomes in spite of the treatments used, and the presence of axillary metastases is a strong indicator of poor prognosis ${ }^{15}$. Therefore, it is important in the clinical practice to better know the tumor characteristics that can predict aggressiveness and axillary involvement. The morphological aspects are directly related to tumors evolution and, in this context, the main determinant is the degree of cellular differentiation $n^{5,16,17}$.
Hammond et al. ${ }^{18}$ and Fitzgibbons et al. ${ }^{19}$ considered $H G$ as the first-choice morphological feature to predict prognosis in cases of breast cancer. Leong et al. ${ }^{20}$ evidenced $\mathrm{HG}$ as a good predictor of prognosis. However, they stated that low-grade tumors might also present unfavorable outcomes, with axillary metastases in cases with a long survival time.

Nevertheless, Younes et al. ${ }^{21}$ studied cases of breast cancer without axillary involvement and could not establish a relationship between $H G$ and the patients'prognosis. Lopes et al.22, analyzing the relationship between $\mathrm{HG}$ and distant recurrence in five years, also did not find statistical significance. Ladekar ${ }^{23}$ considers that there are flaws in the reproducibility of $\mathrm{HG}$ that compromise its clinical applicability as a prognostic factor. In this study, we could not establish a significant correlation between $\mathrm{HG}$ and axillary involvement either.

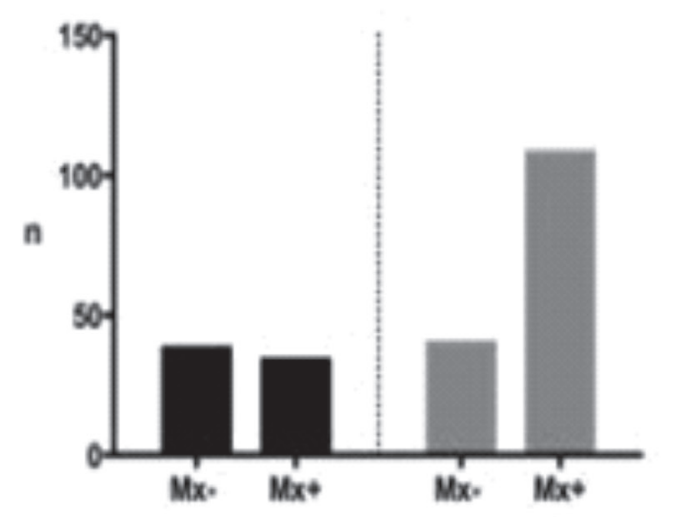

Tumor diameter $\mathbf{X}$ axillary metastasis

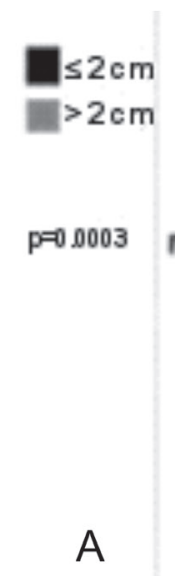

A

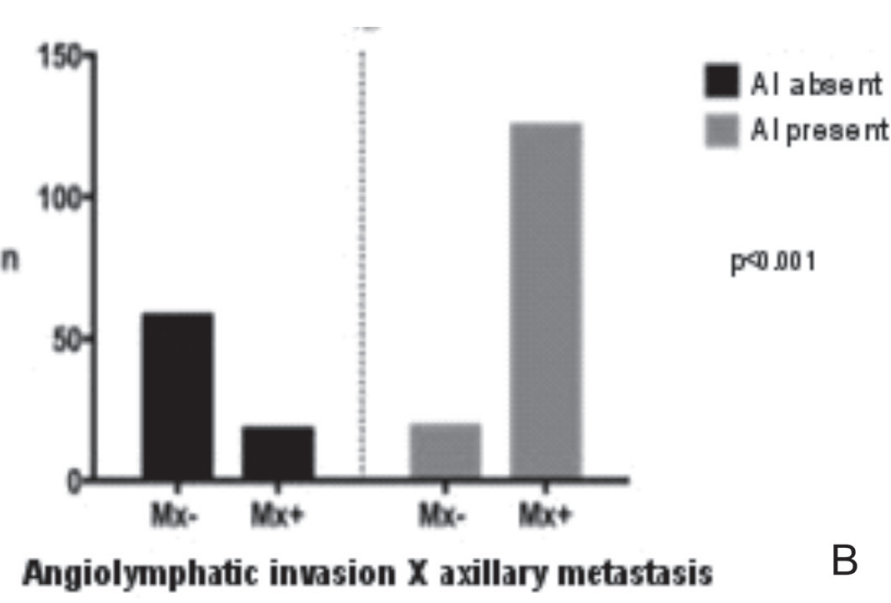

Figure 4. Grouped distribution according to the metastatic involvement of axillary lymph nodes $(n=220)$. A) Tumor diameter; B) Angiolymphatic invasion. 
We did not find a significant relationship between NG and the occurrence of axillary metastases when considered in isolation. This finding is in agreement with those of Lopes et al. ${ }^{22}$, who, studying the relation of the NG with the metastatic relapse in five years, did not observe statistical correlation. Martinez-Arribas et al. ${ }^{24}$ found a direct relation of NG3 with worse prognosis when associated with immunohistochemical parameters, such as absence of hormonal receptors and high Cerb-B2 and Ki67.

$\mathrm{MI}$ is a variable of the histological grade established by counting the number of mitoses per high magnification field. Lopes et al. ${ }^{22}$ showed that a mitotic count greater than ten per field was associated with axillary metastases and with systemic relapse in five years. In the study by Medri et al. ${ }^{25}$, the high number of mitoses was associated with a greater probability of distant metastases in cases of previously negative axilla breast cancer.

Caly et al. ${ }^{26}$, Baak et al. ${ }^{27}$ and van Diest et al. ${ }^{28}$ analyzed $\mathrm{Ml}$ as a prognostic factor and considered it as effective as $H G$, tumor size and NG in cases of breast cancer. In our series, the results agree with the literature presented here, since tumors with high $\mathrm{Ml}$ statistically related with the metastatic involvement of axillary lymph nodes.

Barbosa et al. ${ }^{29}$ observed that tumor size has a significant correlation with axillary lymph node involvement. A meta-analysis involving 11 studies $^{30}$ concluded that tumor size $>2 \mathrm{~cm}$ and angiolymphatic invasion indisputably increase the probability of axillary lymph node involvement. The literature data presented here corroborate the results of our study, which demonstrated that the present Al was significantly associated with axillary metastases and tumor diameter $>2 \mathrm{~cm}$.

High mitotic indexes, tumors with a diameter $>2.0 \mathrm{~cm}$ and the presence of angiolymphatic invasion were individually associated with the occurrence of axillary metastases in the cases studied and should therefore continue to be part of the initial evaluation of breast cancer and direct the conducts despite current molecular and genetic classifications.

\title{
R E S U M O
}

\begin{abstract}
Objetivo: analisar a relação das características anatomopatológicas com o comprometimento axilar em casos de carcinoma ductal invasor. Métodos: estudo transversal de 220 pacientes com câncer de mama, submetidas à mastectomia radical ou quadrantectomia com esvaziamento axilar, oriundos do Serviço de Mastologia da Maternidade Escola Assis Chateaubriand, Ceará, Brasil. Os tumores foram submetidos a processamento histológico e, em seguida, foram determinados os graus histológico (GH), tubular (GT), nuclear (GN), índice mitótico (IM) pela classificação de Scarff-Bloom-Richadson, verificada a presença de invasão angiolinfática (IA) e mensurado o maior diâmetro do tumor (DT). Tais variáveis foram correlacionadas com a presença de metástases axilares. Resultados: a média de idade das pacientes foi 56,81 anos $\pm 13,28$. O tamanho do tumor variou de 0,13 a $22 \mathrm{~cm}$, com média de 2,23cm $\pm 2,79$. Os GH3, GT3 e GN3 prevaleceram: $n=107(48,6 \%), n=160(72,7 \%)$ e $n=107(48,6 \%)$, respectivamente. Os índices mitóticos 1, 2 e 3 apresentaram distribuição homogênea: $n=82(37,2 \%), n=68(31 \%)$ e $n=70(31,8 \%)$, respectivamente. Não foi evidenciada relação do $G H, G T$ e $G N$ com a ocorrência de metástases axilares $(p=0,07 ; p=0,22$ e $p=0,21)$. Índices mitóticos 2 e 3 apresentaram relação com a o ocorrência de metástases axilares $(p=0,03)$. Tumores maiores do que $2 \mathrm{~cm}$ e casos com invasão angiolinfática apresentaram maior índice de metástases axilares ( $p=0,0003$ e p<0,0001). Conclusão: índices mitóticos elevados, tumores com diâmetro maior do que $2 \mathrm{~cm}$ e presença de invasão angiolinfática apresentaram isoladamente relação com a ocorrência de metástases axilares.
\end{abstract}

Descritores: Neoplasias da Mama. Metástase Linfática. Patologia Cirúrgica. Gradação de Tumores.

\section{REFERENCES}

1. Ban KA, Godellas CV. Epidemiology of breast cancer. Surg Oncol Clin North Am. 2014;23(3):409-22.

2. Vich $P$, Brusint $B$, Alvarez-Hernández C, Cuadrado-Rouco C, Diaz-García N, Redondo-Margüello E. Update of breast cancer in primary care $(\mathrm{IN})$. Semergen. 2014;40(6):326-33.

3. Shah R, Rosso K, Nathanson SD. Pathogenesis, prevention, diagnosis and treatment of breast cancer.
World J Clin Oncol. 2014;5(3):283-98.

4. Aquino RGF, Pinheiro LGP, Ferreira MVP, Cavalcante DIM, Oliveira ALS, Gomes NN, et al. Ductal carcinoma of the breast: morphological aspects according to the age. J Bras Patol Med Lab. 2015;51(4):252-7.

5. Elston CW, Ellis IO. Pathological prognostic factors in breast cancer. I. The value of histological grade in breast cancer: experience from a large study with long-term follow-up. Histopathology. 1991;19(5):403-10.

6. Zhang R, Chen HJ, Wei B, Zhang HY, Pang ZG, Zhu 
$H$, Zhang Z, et al. Reproducibility of the Nottingham modification of the Scarff-Bloom-Richardson histological grading system and the complementary value of Ki-67 to this system. Chin Med J (Engl). 2010;123(15):1976-82.

7. Rakha EA, Reis-Filho JS, Baehner F, Dabbs DJ, Decker $T$, Eusebi $V$, et al. Breast cancer prognostic classification in the molecular era: the role of histological grade. Breast Cancer Res. 2010;12(4): 207.

8. Blamey RW, Hornmark-Stenstam B, Ball G, Blichert-Toft M, Cataliotti L, Fourquet A, et al. ONCOPOOL - a European database for 16,944 cases of breast cancer. Eur J Cancer. 2010;46(1):56-71.

9. Rakha EA, El-Sayed ME, Lee AH, Elston CW, Grainge MJ, Hodi Z, et al. Prognostic significance of Nottingham histologic grade in invasive breast carcinoma. J Clin Oncol. 2008;26(19):3153-8.

10. Nikolic-Vukosavljevic D, Kanjer K, Markicevic M, Todorovic-Rakovic N, Vukotic D, Neskovic-Konstantinovic Z. Natural course of node-negative breast cancer: high risk-related subgroups. J Exp Clin Cancer Res. 2003;22(4):543-9.

11. Elston CW, Ellis IO. Pathological prognostic factors in breast cancer. I. The value of histological grade in breast cancer: experience from a large study with long-term follow-up. Histopathology. 2002;41(3A):154-61.

12. Cao Y, Paner GP, Rajan PB. Sentinel node status and tumor characteristics: a study of 234 invasive breast carcinomas. Arch Pathol Lab Med. 2005;129(1):82-4.

13. Chen YW, Lai YC, Hsu CC, Chuang YW, Hou MF. Value of nodal drainage patterns and tumor location from lymphoscintigraphic mapping in detecting axillary sentinel lymph node status in breast cancer: experience at Kaohsiung Medical University Hospital. Kaohsiung J Med Sci. 2005;21(6):251-7.

14. Lopes CM, Montemor Netto MR, Mansani FP, Stival RSM, Cassapula MR, Oliveira TFB. Clinical, histomorphological, and therapeutic progmostic factors in patients with triple-negative invasive breast câncer. 2015;51(6):397-406.

15. Follana $P$, Barrière J, Chamorey E, Largillier R, Dadone B, Mari V, et al. Prognostic factors in 401 elderly women with metastatic breast cancer. On- cology. 2014;86(3):143-51.

16. Fisher ER, Redmond C, Fisher B. Histologic grading of breast cancer. Pathol Annu. 1980;15(Pt 1):239-51.

17. Arihiro K. Pathological approach to evolving prognostic and predictive factors of breast cancer. Breast Cancer. 2004;11(4):343-9.

18. Hammond ME, Fitzgibbons $\mathrm{PL}$, Compton CC, Grignon DJ, Page DL, Fielding LP, et al. College of American Pathologists Conference XXXV: solid tumor prognostic factors-which, how and so what? Summary document and recommendations for implementation. Cancer Committee and Conference Participants. Arch Pathol Lab Med. 2000;124(7):958-65.

19. Fitzgibbons $P L$, Page $D L$, Weaver $D$, Thor $A D, A l l-$ red DC, Clark GM, et al. Prognostic factors in breast cancer. College of American Pathologists Consensus Statement 1999. Arch Pathol Lab Med. 2000;124(7):966-78.

20. Leong AC, Hanby AM, Potts HW, Tan DS, Skilton $D$, Ryder K, et al. Cell cycle proteins do not predict outcome in grade I infiltrating ductal carcinoma of the breast. Int J Cancer. 2000;89(1):26-31.

21. Younes M, Laucirica R. Lack of prognostic significance of histological grade in node-negative invasive breast carcinoma. Clin Cancer Res. 1997;3(4):601-4.

22. Lopes LAF, Ferraro O, Linhares JJ, Lopes RGC, Baracat FF. Valor prognóstico do grau histológico (GH), grau nuclear (GN) e índice mitótico (IM) para pacientes com carcinoma da mama estádios II e III com linfonodos axilares comprometidos. Rev bras cancerol. 2006;52(3):245-51.

23. Ladekarl M. Objective malignancy grading: a review emphasizing unbiased stereology applied to breast tumors. APMIS Suppl. 1998;79:1-34.

24. Martínez-Arribas F, Martín-Garabato E, Lafuente P, Tejerina A, Lucas R, Sánchez J, et al. Proliferation measurement in breast cancer by two different methods. Anticancer Res. 2006;26(1A):199-202.

25. Medri L, Volpi A, Nanni O, Vecci AM, Mangia A, Schittulli $F$, et al. Prognostic relevance of mitotic activity in patients with node-negative breast cancer. Mod Pathol. 2003;16(11):1067-75. 
26. Caly M, Genin P, Ghuzlan AA, Elie C, Fréneaux $\mathrm{P}$, Klijanienko J, et al. Analysis of correlation between mitotic index, MIB1 score and S-phase fraction as proliferation markers in invasive breast carcinoma. Methodological aspects and prognostic value in a series of 257 cases. Anticancer Res. 2004;24(5B):3283-8.

27. Baak JP. The relative prognostic significance of nucleolar morphometry in invasive ductal breast cancer. Histopathology. 1985;9(4):437-44.

28. van Diest PJ, Baak JP, Matze-Cok P, Wisse-Brekelmans EC, van Galen CM, Kurver PH, et al. Reproducibility of mitosis counting in 2,469 breast cancer specimens: results from the Multicenter Morphometric Mammary Carcinoma Project. Hum Pathol. 1992;23(6):603-7.

29. Barbosa EM, Francisco AARF, Araujo Neto JT, Alves EMF, Tavares MGM, Góes JCS. Fatores clínico-patológicos de predição do acometimento axilar em pacientes com metástases de câncer de mama no linfonodo sentinela. Rev Bras Ginecol Obstet. 2010;32(3):144-9.

30. Degnim AC, Griffith KA, Sabel MS, Hayes DF, Cimmino VM, Diehl KM, et al. Clinicopathologic features of metastasis in nonsentinel lymph nodes of breast carcinoma patients. Cancer. 2003;98(11):2307-15.

Received in: 13/09/2016

Accepted for publication: 11/10/2016

Conflict of interest: none.

Source of funding: Coordination of Improvement of Higher Level Personnel - CAPES.

\section{Mailing address:}

Ranniere Gurgel Furtado de Aquino

E-mail: rannieregurge|@hotmail.com

rannieregurgel@gmail.com 